Otentik's: Jurnal Hukum Kenotariatan (Vol 2, No. 1, Januari 2020)

p-ISSN 2655-5131 e-ISSN 2685-3612

\title{
PENGEMBALIAN HAK ATAS TANAH BERSERTIPIKAT HAK GUNA BANGUNAN YANG TELAH MUSNAH KARENA ABRASI UNTUK KEPENTINGAN PEMBANGUNAN OLEH BADAN HUKUM SWASTA
}

\author{
Syaiful Bahri \\ Email: syaifulbahri@gmail.com
}

\begin{abstract}
Abstrak
Setiap hak atas tanah pada dasarnya memiliki fungsi petuntukkan dan pemanfaatan untuk tujuan penatagunaan tanah secara optimal dan kesesuaian lingkungan. Tanah dapat diperuntukkan pertaniaan dengan pemanfaat untuk pengembangan bahan pokok dan di lain bidang dapat diperuntukkan untuk pembangunan dengan pemanfaatan peningkatan infratruktur menjadikan lahan produktifitas pengembangan ekonomi. Hak penguasai negara atas tanah, mengatur penatagunaan tanah dengan peruntukkan dan pemanfaatan, serta mengatur hubungan-hubungan hukum tanah dengan pemegang hak dengan tujuan sosialisme Indonesia, yaitu mencapai sebesar-besarnya kemakmuran rakyat Indonesia sesuai amanat oleh UUD 1945. Permukaan bumi paling atas (tanah), memiliki peran dan obyek yang sangat penting dalam kehidupan manusia terutama bagi negara, karena keadaan jumlahnya yang terbatas, dan berbagai kepentingan diperlukan Negara. Untuk itu negara mengatur pemanfaatan tanah sesuai dengan peruntukkannya, beserta kewajiban untuk menjaga dan merawat agar terhindar dari Ketidakmanfaatan (ditelantarkan) dan Musnah Tanahnya. Setiap bentuk kelembagaan hak-hak atas tanah diberikan telah diformulasikan dengan tujuan peruntukkan suatu maksud tertentu oleh Negara, dibarengi dengan kewajiban dipenuhi oleh setiap pemegang haknya, terutama sekali badan hukum. Keadaan pembiaran dengan kesengajaan tidak termanfaatkan tanah sesuai tujuan pemberian hak, dapat mengakibatkan hapusnya hak disebabkan perilaku ketidakperdulian pentingnya fungsi sosial tanah, keadaan musnahnya tanah karena fenomena alam, yang menghapus kepemilikkan tanah, langsung merugikan pemegang hak, dengan konsekuensi tidak ada kewajiban negara menganti-rugian karena keadaan musnah merupakan force majure (kahar), diluar kekuasaan pencegahan. Upaya pengembalian kondisi tanah seperti semula dapat dilumrahkan jika sesuai dengan ketentuan perundangan dengan penyesuaian penataagunaan dan lingkungan hidup, dengan tujuan pengembalian hak atas tanah.
\end{abstract}

Kata kunci : Tanah Musnah, Peruntukkan. Pengembalian Hak

\begin{abstract}
Every land rights basically has allocation and utilization functions. Those functions are intended for optimal land use and environmental suitability. Land can be allocated for agriculture by using it to develop staples. In addition, in other fields, land can also be allocated for development by utilizing it to increase infrastructure in order to make land productive economic development. The state's right to control land, regulate land use by allocation and use, and regulate land legal relations with rights holders with the aim to uphold Indonesian socialism, which is to achieve the maximum prosperity of the Indonesian people according to the mandate of the 1945 Constitution. Land has a role and is an object that is very important in human life, especially for the state. This is due to the limited number and various interests of the state itself. For this reason, the state regulates the use of land in accordance with its allocation, along with the obligation to protect and maintain it so that it can avoid being used and abandoned. Every institutional form of land rights granted has been formulated with the aim of designating a specific purpose by the State, accompanied by obligations fulfilled by each of the
\end{abstract}


Otentik's: Jurnal Hukum Kenotariatan (Vol 2, No. 1, Januari 2020)

p-ISSN 2655-5131 e-ISSN 2685-3612

rights holders, especially by legal entities. Deliberate abandonment of a land in accordance with the purpose of granting rights can result in the loss of rights due to the indifference of the importance of the social function of the land. Destruction of land due to natural phenomena, which removes land ownership will directly harm the right-holders, making there is no obligation for the state to provide compensation as the consequence because the destruction of the land is considered as force majeure which is outside the preventive power. Efforts to restore the land condition can be laid off if in accordance with the provisions of the law with adjustments to the use of the environment and environment, with the aim of returning the land rights.

Keywords: Destruction of Land, Allocation, Return of Rights

\section{PENDAHULUAN}

Tanah merupakan obyek hukum yang sangat dibutuhkan oleh manusia, karena tanpa tanah manusia tidak akan bisa menjalani kehidupan dengan sempurna (manusia dapat juga hidup diatas air dengan perahu). Hal ini disebabkan bahwa tanah menjadi tempat berpijak yang baik bagi setiap umat manusia dan sekaligus sebagai tempat keberlangsungan hidup manusia yang hakiki, mulai sejak lahir sampai manusia meninggal pun manusia membutuhkan tanah, karena manusia meninggal dikubur dalam tanah (kecuali sebagian keyakinan agama tidak serta merta memerlukan tanah sebagai penguburan jenazah, bisa saja dibakar atau ditenggelamkan ke laut), sesuai dengan hukum kodrat alam dan hukum keyakinan Agama Samawi (Ibrahimiah), bahwa manusia diciptakan oleh Allah Tuhan Yang Esa berasal dari tanah. Maka oleh karena itu tanah adalah merupakan bagian hidup manusia.

Disamping tanah merupakan kebutuhan hidup manusia dan bagian hidup manusia, tanah juga sebagai sentral pembangunan yang mempunyai nilai ekonomi dan bisnis. Hal mana dapat kita pahami pembangunan memerlukan tanah baik usaha maupun investasi jangka pendek, menengah maupun jangka panjang.

Tanah merupakan salah satu unsur utama dari suatu kegiatan pembangunan, hamparan permukaan bumi yang diolah dan dikembangkan dengan pola dan tujuan menciptakan dan mengembangkan fungsi dari hamparan permukaan bumi yang tidak produktif menjadi hamparan permukaan bumi bernilai (prospek) dengan kegiatan untuk pembangunan.

Permukaan bumi (tanah) yang menjadi sumber dari kepentingan pelaksanaan pembangunan merupakan sumber daya alam karunia Tuhan Yang Maha Esa kepada Bangsa Indonesia, pengelolaan untuk dapat dilakukan dengan pemanfaatan sebaik baiknya, agar dapat memberikan kemakmuran rakyat sebagaimana yang telah diamanatkan dalam pasal 33 ayat (3) Undang-Undang Republik Indonesia 1945, yang selajutnya disebut UUD 1945, dalam amanat penjelasan bahwa Negara sebagai organisasi kekuasaan rakyat yang tertinggi merupakan alat untuk memimpin penggunaan bumi, air dan kekayaan alam yang terkandung di dalamnya, dalam pengaturan- pengaturannya yang tercakup didalam seluruh kekuasaan kedaulatan Bangsa Indonesia dengan tujuan sebesar-besarnya kemakmuran rakyat.

Dalam hal pelaksanaan pengaturan hukum pertanahan dapat kita jumpai landasan rumusan pasal 33 ayat (3) UUD 1945 dalam pasal 2 UUPA ayat (1) yang mengkonkritkan dengan dinyatakan sebagai berikut :

"Atas dasar ketentuan pasal 33 ayat 3 Undang - Undang Dasar dan hal - hal yang dimaksud dalam pasal, bumi, air dan ruang angkasa, termasuk kekayaan alam yang terkandung didalamya itu pada tingkatan tertinggi dikuasai oleh Negara, sebagai organisasi kekuasaan seluruh rakyat" 
Pembangunan dan penguasaan tanah harus merupakan pembangunan berkelanjutan yang berwawasan lingkungan, yaitu pembangunan secara sadar dan terencana, yang memadukan lingkungan hidup, termasuk sumber daya, kedalam proses pembangunan untuk menjamin kemampuan, kesejahteraan dan mutu hidup generasi masa kini dan generasi masa depan. ${ }^{1}$

Dalam pasal 4 ayat (1) UUPA dinyatakan bahwa atas dasar hak menguasai dari Negara dalam hukum pertanahan sebagai yang dimaksud dalam pasal 2 UUPA ditentukan adanya macammacam hak atas permukaan bumi, yang disebut tanah, yang dapat diberikan kepada dan dipunyai oleh orang-orang, baik sendiri maupun bersama-sama dengan orang-orang lain serta badan-badan hukum. Dengan demikian jelaslah bahwa tanah dalam pengertian yuridis adalah permukaan bumi, sedangkan hak atas tanah adalah hak atas sebagian tertentu permukaan bumi, yang terbatas, berdemensi dua dengan ukuran panjang lebar. ${ }^{2}$

Sebagai bangsa yang berdaulat hukum Pertanahan (agraria sempit) amat diperlukan sekali memahami tentang pengalihan hak atas tanah, dan hak-hak yang melekat di atas tanah tersebut, termasuk mengenai bagian-bagian dari tanah, musnahnya karena fenomena alam (vernietigde het land) dan bagaimana terjadinya/lahirnya tanah timbul dikarenakan proses pengembalian permukaan tanah dengan proses revitalisasai (Revitalisatie van het land) dan tanah timbul (Aanslibbing). Yang sangat dibutuhkan sejalan dengan perkembangan masyarakat dan pembangunan agar penerangan tentang masalah agraria dalam arti sempit (tanah) yang terjadi karena musnah, revitalisasi dan timbul dapat di jelaskan dan menjadi pedoman dan/atau pemahaman kepada masyarakat yang merupakan bagian dari pembangunan serta pihak-pihak terkait seperti pemerintah sebagai regulator, dan salah satunya subyek badan hukum baik pemerintah atau swasta sebagai pelaku pembangunan. Dalam hal hapusnya hak karena gejala alam yang mengakibatkan musnah tanahnya, seperti yang ditetapkan dalam pasal 40 huruf (f) UUPA dijelaskan "Hak Guna Bangunan hapus salah satunya karena tanahnya musnah", perlu mendapat perhatian bagi pemegang hak atas tanah bersertipikat mempunyai fungsi peruntukkan, perencanaan dan penggunaan.

Oleh karena, bagi pihak yang telah menguasai tanah dengan suatu hak sesuai ketentuan UUPA atau penguasaan lainnya, harus menggunakan dan memanfaatkan tanahnya sesuai keadaan, sifat dan tujuan pemberian haknya. Dengan kata lain, para pemegang hak atas tanah maupun penguasaan tertentu tidak membiarkan musnahnya tanah dengan menelantarkan tanahnya, menjadi tanah kosong atau tidak produktif. Dalam kaitan penguasaan hak atas tanah apapun macamnya, kewajiban utama dari pemegang hak tersebut haruslah dimaksimalkan pemanfaatannya, pelanggaran terhadap pemberian ini dapat menjadikan Negara mengambil kembali pemberian hak tersebut melalui berbagai cara menurut hukum yang berlaku, diantara mencabut kembali, sehingga dapat diartikan tanah tersebut dapat dikuasai kembali oleh Negara.

Gempa bumi dan bencana alam adalah fenomena alamiah yang dapat serta sering terjadi di mana saja dan kapan saja, faktor utama itu yang dapat mengakibatkan permukaan bumi (tanah) tidak sama sekali tidak dapat lagi dikuasai fisik dan secara fisik tidak diketahui keberadaannya. Bagi proses pembangunan fenomena alamiah ini dapat menganggu dan mungkin mengkibatkan kemunduran serta bisa tidak terlaksananya rencana pemanfaat lahan sesuai peruntukkan dan fungsinya dalam pembangunan. Kegiatan pengadaan tanah yang dilakukan untuk pelaksanaan penanaman modal untuk pembangunan, akan terdelusi oleh alam, karena berkurangnya atau hilangnya obyek pembangunan. Dalam pasal 40 huruf (f), bahwa Hak Guna banguna dapat hapus karena; .... (f) musnah tanahnya, maka dengan seketika tidak adanya permukaan bumi (tanah) tidak sama sekali tidak dapat lagi dikuasai fisik dan secara fisik tidak diketahui keberadaannya, maka seketika hapus hak atas tanahnya. Atas sertipikat hanya kebenaran administrasi negara mengenai atas wilayah bumi (tanah) yang musnah pernah

${ }^{1}$ Hutagalung Arie S, Tebaran Pemikiran Seputar Masalah Hukum Tanah, cet.1. (Jakarta: Lembaga Penelitian Hukum Indonesia, 2005), hlm. 19

2 Ibid. 
diberikan hak dan tidak berlaku sebagai bukti kepemilikkan tanah, atas itu tidak bisa dipergunakan obyek hubungan-hubungan hukum atas tanah, seperti menjual dan menjaminkan sertipikat tersebut, yang mengakibatkan cacat hukum setiap hubungan hukum yang dialakukan atas sertipikat tanah tersebut, seperti hak tanggungan. berikut :

Berdasrkan rumusan latar belakang maka perumusan masalah oleh penulis sebagai

1. Bagaimana pengembalian hak kepemilikkan tanah bersertipikat yang telah musnah karena abrasi ?

2. Bagaimana kedudukan hukum kepemilikkan hak atas tanah yang telah bersertipikat yang terkena abrasi menurut UUPA

\section{METODE PENELITIAN}

Mengadakan suatu penelitian ilmiah jelas harus menggunakan metode, karena ciri khas ilmu adalah dengan menggunakan metode. Metode berarti penyelidikan yang berlangsung menurut suatu rencana tertentu, metode dalam bahasa Inggris disebut method dalam bahasa latin disebut juga methodus dan dalam bahasa Yunani disebut methodos yang memiliki arti sesudah, diatas, sedangkan hodos berarti suatu jalan atau suatu cara, menurut Van Peursen menerjemahkan pengertian metode secara harfiah, mula-mula metode diartikan sebagai suatu jalan yang harus ditempuh kemudian menjadi penyelidikan atau penelitian berlangsung menurut suatu rencana tertentu. Dalam pengertian riset penelitian merupakan aplikasi atau penerapan metode yang telah ditentukan dengan persyaratan yang sangat ketat berdasarkan tradisi keilmuan yang terjaga sehingga hasil penelitian yang dilakukan memiliki nilai ilmiah yangdihargai oleh komunitas ilmuan terkait.

Untuk tujuan penelitian tersebut metode penelitian dibuat sebagai berikut :

a) Tipe Penelitian :Metode penelitian hukum kepustakaan yaitu metode atau cara yang dipergunakan dengan meneliti bahan pustaka yang ada. Penelitian yang dilakukan bersifat deskriptif yaitu menggambarkan gejala-gejala di lingkungan masyarakat terhadap suatu kasus yang diteliti, pendekatan yang dilakukan yaitu pendekatan kualitatif yang merpakan tata cara penelitian yang mnghasilkan data deskriptif.

b) Bahan hukum

Uraian tentang bahan hukum yang dikaji meliputi beberapa hal antara lain :

Bahan hukum primer yakni bahan hukum yang terdiri atas Peraturan perundangundangan yang diurut berdasarkan hierarki Undang-Undang dan bahan hukum sekunder adalah bahan hukum yang terdiri atas buku-buku teks yang ditulis para ahli hukum, jurnal-jurnal hukum, pendapat para sarjana hukum, kasus-kasus hukum, Bahan hukum tersier adalah bahan hukum yang memberikan petunjuk atau penjelasan terhadap bahan hukum premier dan bahan hukum sekunder seperti kamus hukum, encyclopedia.

\section{PEMBAHASAN.}

A. Aspek Pengembalian Hak Kepemilikkan Tanah Bersertipikat Yang Telah Musnah Karena Abrasi

Ketentuan Pasal 2 ayat (1), (2) dan (3) menentukan kewenangan Negara sebagai oranisasi kekuasaan seluruh rakyat yang menguasai bumi, air dan ruang angkasa, termasuk kekayaan alam yang terkandung di dalamnya, dan berwenang untuk mengatur dan menyelenggarakan peruntukkan, penggunaan, persediaan, pemeliharaan, menentukan dan mengatur hubunganhubungan antara orang-orang dan perbuatan-perbuatan hukum yang mengenai bumi, air dan angkasa.

Hak menguasai dari Negara tersebut diatas pelaksanaannya dapat dikuasakan kepada daerah dalam watantra dan masyarakat-masyarakat hukum adat, sekedar diperlukan dan tidak bertentangan denga kepentingan nasional, menurut ketentuan-ketentuan Peraturan Pemerintah. 
Ketentuan dalam Pasal 2 ayat (4) adalah bersangkutan dengan asas otonomi dan medebewind dalam penyelenggaraan pemerintah daerah, soal agraria menurut sifatnya danpada dasarnya merupakan tugas Pemerintah Pusat (Pasal 33 ayat (3) UUD), dengan demikian maka pelimpahan wewenang untuk melaksanakan hak penguasaan dari negara atas tanah itu adalah merupakan medebewin. Segala sesuatunya akan diselenggarakan menurut keperluannya dan sudah barang tentu tidak boleh bertentngan dengan kepentingan nasional. Wewenang dalam bidang agraria dapat merupakan sumber bagi daerah itu.

Wewenang Negara yang bersumber pada hak menguasai tanah oleh negara dipegang oleh pemerintah pusat, sehingga bersifat sentralisasi, Pemerintah daerah dapat mempunyai wewenang tersebut apabila ada pelimpahan wewenang dari pemerintah pusat kepada pemerintah daerah (tugas perbantuan/medebewin).

Sejak berakhirnya pemerintah Orde Baru, terjadi reformasi dalam segala tatanan kehidupan bernegara, yang menuntut di dalamnya perubahan dalam segala tatanan kehidupan bernegara. Salah satunya perubahan yang terjadi dibidang pemerintah adalah berakhirnya suatu orde pemerintahan yang bersifat sentralistik menjadi pemerintahan yang bersifat desentralistik, yang artinya Pemerintah Daerah diberi otonomi seluas-luasnya, kecuali urusan pemerintahan yang oleh Undang-Undang ditentukan sebagai urusan Pemerintah Pusat, sebagaimana secara tegas dinyatakan Pasl 18 ayat (5) UUD 1945.

Dalam era reformasi Negara Kesatuan Republik Indonesia sebagai negara kesatuan yang memuat azas desentralisasi dalam penyelenggaraan pemerintah, memberikan kesempatan dan keleluasaan yang selua-luasnya kepada Pemerintah Daerah untuk melaksanakan dan menyelenggarakan pemerintahannya sendiri. (Pasal 18 ayat (5) UUD 1945).

Dalam ketentuan Undang Nomor 22 Tahun 1999 dijelaskan kewenangan menganut azas otonomi daerah seluas-luasnya sebagaimana diatur dalam Pasal 7 yang berbunyi, sebagai berikut:

a) Kewenangan daerah mencakup kewenangan dalam seluruh bidang pemerintahan, kecuali kewenangan dalam bidang politik luar negeri, pertahanan keamanan, keadilan, moneter fiskal, agama, serta kewenangan bidang lain.

b) Kewenangan bidang lain, sebagaimana termaksud pada ayat (2), meliputi kebijakan tentang perencanaan nasional dan pengendalian pembangunan nasional secara makro, dana perimbangan keuangan, sistem administrasi negara dan lembaga perekonomian negara, pembinaan dan pemberdayaan sumber daya manusia, pendayagunaan sumber daya alam serta tehnologi tinggi yang strategis, konservasi dan standarisasi nasional.

Menurut Pasal 7 tersebut, Pemerintah Daerah mempunyai semua kewenangan di bidang pemerintahan kecuali wewenang yang oleh Undang-Undang diberikan kepada Pemerintah Pusat yaitu olitik luar negeri, pertahanan keamanan, keadilan, moneter, fiskal, agama, dan di bidang lainnya sebagaimana dirinci oleh Pasal 7 ayat (2) tersebut. Bidang pertanahan tidak termasuk kewenangan yang diberikan kepada Pemerintah Pusat, sehingga kewenangan dibidang pertanahan itu dipagang oleh Pemerintah Daerah.

Selanjutnya pembagian kwenangan antara Pemerintah Daerah dengan Pemerintah Pusat diatur dalam Peraturan Pemerintah Nomor 25 Tahun 2000 tentang "Kewenangan pemerintah dan kewenangan propinsi sebagai daerah ototnomi". Dalam Pasal 2 ayat (3) Nomor 14 Peraturan Pemerintah tersebut, merinci kewenngan Pemerintah Pusat dibidang pertanahan, yaitu:

a. Penetapan persyaratan pemberian hak-hak atas tanah.

b. Penetapan persyaratan landreform.

c. Penetapan standar administrasi pertanahan.

d. Penetapan pedoman biaya pelayanan pertanahan.

e. Penetapan kerangka Dasar Kadastral Nasional dan pelaksanaan pengukuran Kerangka Dasar Kadastral Nasional Orde I dan II. 
Otentik's: Jurnal Hukum Kenotariatan (Vol 2, No. 1, Januari 2020)

p-ISSN 2655-5131 e-ISSN 2685-3612

Berdasarkan ketentuan pasal tersebut, Pemerintah Pusat hanya diberi wewenang untuk menetapkan standarisasi, hal-hal tersebut diatas, sedang kebijakan dibidang pertanahan dipegang oleh Pemerintah Daerah.

Pada tanggal 15 Oktober 2004, diberlakukan Undang-Undang Nomor 32 Tahun 2004 yang dalam Pasal 239 secara tegas mencabut berlakunya Undang-Undang Nomor 22 Tahun 1999.

Undang-Undang ini pun memberi kewenangan yang seluas-luas kepada Pemerintah Daerah untuk menyelenggarakan pemerintahannya, sebagaimana diatur dalam pasal 10 yang berbunyi sebagai berikut:

a) Pemerintah Daerah menyelenggarakan urusan pemerintah yang menjadi kewenangannya, kecuali urusan pertanahan yang oleh Undang-Undang ini ditentukan menjadi urusan Pemerintah.

b) Dalam menyelenggarakan urusan pemerintah yang menjadi kewenangan daerah sebagai dimaksud pada ayat (1), pemerintah daerah menjalankan otonomi seluas-luasnya untuk mengatur dan mengurus sendiri urusan pemerintahan berdasarkan atas otonomi dan tugas perbantuan.

Menurut kedua pasal tersebut, salah satu urusan wajib Pemerintahan Daerah baik provinsi maupun kabupaten/kota adalah pelayanan pertahanan. Masalah yang timbul berkenaan dengan ketentuan kedua pasal tersebut adalah apakah kewenangan membuat kebijakan (policy) di bidang pertahanan, ataukah termasuk membuat kebijakan di bidang pertahanan.

Pada tanggal 11 April 2006, dengan diberlakukannya Peraturan Presiden Nomor 10 Tahun 2006, tentang Badan Pertanahan Nasional, maka semua kewenangan yang berkaitan dengan Pelayanan pertanahan yang dimak

sud dalam Pasal 14 ayat (1) huruf (k) diberikan kepada Badan pertanahan Nasional, sebagaimana yang diatur dalam Pasal 2 yang berbunyi: Badan Pertanahan Nasional (BPN) melaksanakan tugas pemerintahan dibidang pertanahan secara nasional, regional, dan sektoral.

Maka dalam pelaksanaan pemanfaatan lahan untuk penanaman modal untuk pembangunan, dengan jelas diketahui kewenangan-kewenangan sebagai berikut :

a) Perencanaan dan pengendalian pembangunan, Perencanaan, pemanfaatan, dan pengawasan tata ruang, Pengendalian lingkungan hidup dan Pelayanan administrasi penanaman modal menjadi kewenangan Pemerintah Kabupaten/kota

b) Pelayanan pertanahan menjadi kewenangan Badan Pertanahan Nasional yang merupakan tugas perimbangan dari Pemerintah Pusat, dalam bidang Pertanahan.

Dari kewajiban penetapan-penetapan tersebut diatas yang menjadi komponen pemanfaatan peruntukkan tanah untuk penanaman modal dalam pembangunan, yang menjadi masing- masing kewenangan Pemerintah Daerah Kabupaten/Kota dan Kantor Badan Pertanahan Nasional, sebagai berikut :

1) Penetapan kewenangan Pemerintah Daerah Kabupaten/Kota

a) Perseoran Penanam Modal (TDP dan SIUP, sekarang menjadi NIB)

b) Pertimbangan teknis pemanfaatan lahan

c) Ijin Lokasi

d) Dokumen analisis dampak lingkungan

e) Ijin peruntukkan penggunaan tanah untuk IMB

f) Andalalin

g) Peil Banjir

h) Rencana Induk Master Plan

2) Penetapan kewenangan Kantor Badan Pertanahan Nasional

a) Aspek Tata Guna Tanah

b) Pendaftaran Tanah 
Otentik's: Jurnal Hukum Kenotariatan (Vol 2, No. 1, Januari 2020)

p-ISSN 2655-5131 e-ISSN 2685-3612

Adapun penetapan pemerintah yang dibutuhkan dalam rangka pemanfaatan peruntukkan tanah penananaman modal untuk pembangunan berdasarkan peraturan perundangan diatas, dengan pertahapan, sebagai berikut :

1) Pertimbangan teknis pemanfaatan lahan dimohonkan kepada Pemerintah

Kabupaten/Kota, sebagai ijin prinsip atas kesusaian Peraturan Daerah tentang Rencana Tata Ruang.

2) Aspek Tata Guna Tanah kepada Kantor Badan Pertanahan Nasional setempat dimana lokasi tanah yang akan dilakukan rencana penanaman modal untuk pembangunan dilaksanakan.

3) Ijin Lokasi diajukan kepada Pemerintah Daerah Dinas Pertanahan dan Tata Ruang.

Izin lokasi merupakan izin yang diberikan kepada Perusahaan untuk memperoleh tanah yang diperlukan dalam rangka penanaman modal yang berlaku pula izin pemindahan hak, dan untuk menggunakan tanah tersebut guna kepeluan usaha penanaman modal.

Bahwa pemberian izin lokasi pada dasarnya merupakan pengarahan lokasi penanaman modal sebagai pelaksanaan penataan ruang dalam aspek pertanahan, hal ini di atur dalam Peraturan Menteri Negara Agraria/Kepala Badan Pertanahan Nasional nomor : 2 tahun 1999 tentang izin lokasi, yang mengatur penanaman modal mengenai keharusan diperoleh izin lokasi sebelum suatu Perusahaan memperoleh tanah yang diperlukan untuk melaksanakan rencana penanaman modal.

4) Pendaftaran Tanah diajukan kepada Kantor Badan Pertanahan Nasional.

Untuk mendapatkan kepemilikkan atas sertipikat Hak Guna Bangunan dapat dilakukan sesuai dengan Keputusan Menteri Negara Agraria/Kepala Badan Pertanahan Nasional Nomor 21 Tahun 1994 tentang Tata Cara Perolehan Tanah

Bagi Perusahaan Dalam Rangka Penanaman Modal yang dimaksudkan, selanjutnya disebut Kep.MNA 21/1994 sebagai pelaksanaan lebih lanjut Peraturan Menteri Negara Agraria/Kepala Badan Pertanahan Nasional Nomor 2 Tahun 1993 tentang Tata Cara Memperoleh Izin Lokasi dan Hak Atas Tanah Bagi Perusahaan Dalam Rangka Penanaman Modal.

1 Peroleh hak kepemilikkan tanah penanaman modal untuk pembangunan dari Perusahaan perlu dipahami terlebih dahulu perihal kedudukan musnahnya tanah HGB, dapat dikatakan tanah yang ditelantarkan dan mengakibatkan hapusnya hak kepemilikkan yang diatur dalam 40 huruf (e) dan (f) dinyatakan bahwa "Hak bangunan hapus karena ... (e) ditelantarkan (f) tanahnya musnah..", untuk itu dapat ditelaah perihal tanah yang dalam izin lokasi tersebut ditelantarkan yang dapat menghapuskan hak kepemilikkan, dapat dikatakan karena 2 (dua) faktor hal tanah dapat dikatakan tidak ditelantarkan dikarenakan :

1) terjadi kenyataan telah dilakukan pembangunan faktor force majure/keadaan kahar, dan;

2) karena pengecualian yang disyaratkan oleh Peraturan perundangan.

Sebelumnya kita mengulang kembali pengertian telah dijabarkan pada bab II, tentang hapusnya kepemilikkan hak atas tanah karena ditelantarkan, maka dapat dilihat terlebih dahulu pengertian dari tanah terlantar. Dalam Perkaban 4/2010 perihal Tata Cara Penertiban Tanah Terlantar, dijelaskan maksud ketelantaran terhadap tanah. Tanah yang diindikasi terlantar adalah tanah yang diduga tidak diusahakan, tidak dipergunakan, atau tidak dimanfaatkan sesuai dengan keadaan atau sifat dan tujuan pemberian hak atau dasar penguasaannya yang belum dilakukan identifikasi dan penelitian (pasal 1 angka 5 Perkaban 4/2010). Dan tanah terlantar adalah tanah yang sudah diberikan hak oleh negara berupa hak milik, hak guna usaha, hak guna bangunan, hak pakai, dan hak pengelolaan, atau dasar penguasaan atas tanah yang tidak diusahakan, tidak dipergunakan, atau tidak dimanfaatkan sesuai dengan keadaannya atau sifat dan tujuan pemberian hak atau dasar penguasaannya (pasal 1 angka 5 Perkaban 4/2010). 
Otentik's: Jurnal Hukum Kenotariatan (Vol 2, No. 1, Januari 2020)

p-ISSN 2655-5131 e-ISSN 2685-3612

Tanah terlantar yang dalam merupakan tanah yang oleh negara telah diberikan hak berdasarkan penetapan pemerintah untuk penguasaan atas tanah yang tidak diusahakan, tidak dipergunakan, atau tidak dimanfaatkan sesuai tujuan keadaannya atau sifat dan tujuan pemberian hak atau dasar penguasaannya, sesuai dengan izin lokasi, surat keputusan pemberian hak dan surat keputusan penetapan lainnya dari pejabat yang berwenang.

Setiap pemberian hak kepada orang atau badan hukum oleh negara selalu diiringi kewajiban-kewajiban yang ditetapkan dalam UUPA dan peraturan perundang-perundangan serta keputusan-keputusan yang berkaitan dengan hak tersebut. Oleh sebab itu Pemegang Hak dilarang menelantarkan tanahnya, karena UUPA telah mengatur akibat hukumnya yaitu hapusnya hak atas tanah yang bersangkutan yang mengakibatkan pemutusan hubungan hukum serta ditegaskan sebagai tanah yang dikuasai langsung oleh Negara.

Dalam UUPA rumusan tanah terlantar masih begitu abstrak, mengingat sifatnya sebagai undang-undang pokok pengaturan, maka diperlukan peraturan yang bersifat operasional terhadap fenomena tanah terlantar, maka Pemerintah telah mengatur perihal tanah terlantar dengan Peraturan Pemerintah Republik Indonesia nomor 11 tahun 2010 selanjut disebut PP 11/2010, yang sebelumnya perbaikan dari Peraturan Pemerintah Republik Indonesia nomor 36 tahun 1998 , yang selanjutnya disebut PP 36/1998 tentang Penertiban dan Pendayagunaan Tanah Terlantar. Untuk untuk memudahkan penafsiran kriteria dan prosedural operasional pelaksanaan penangulangan tanah ditelantarkan.

Hapusnya hak karena tanah terlantar akan jatuh menjadi tanah negara seperti yang diatur dalam UUPA, apabila tanah tersebut dengan sengaja tidak digunakan oleh pemegang haknya sesuai dengan keadaannya atau sifat dan tujuan haknya atau tidak dipelihara dengan baik. Memperhatikan hal diatur dalam UUPA tentang tanah terlantar dapat disimpulkan dengan terjadi karena faktor "kesengajaan", yang dalam PP 11/2010 jo 5 Perkaban 4/2010 maksud :

"kesengajaan dengan kata-kata penguasaan atas tanah yang tidak diusahakan, tidak dipergunakan, atau tidak dimanfaatkan sesuai dengan keadaannya atau sifat dan tujuan pemberian hak atau dasar penguasaannya".

Pengertian kriteria ditelantarkan (kesengajaan ditelantarkan) dapat ditemui pertegasan, dalam PP 36/1998 pasal 3, yang menyatakan :

"Tanah Milik, HGU, HGB atau Hak Pakai dapat dinyatakan sebagai tanah terlantar apabila tanah tersebut dengan sengaja tidak dipergunakan oleh pemegang haknya sesuai dengan keadaannya, tidak dipergunakan oleh pemegang haknya sesuai dengan keadaan atau sifatnya dan tujuan haknya atau tidak dipelihara dengan baik'.

Kata kunci kriteria ditelantarkan berdasarkan ketentuan diatas adalah dengan sengaja tidak dipergunakan dan tidak dipelihara dengan baik.

Syarat pengcualian tanah ditelantarkan diatur dalam peraturan perundangan yang mengatur hal tersebut, dalam hal pengecualian karena kriteria tanah terlantar bagi perorangan yang ditegaskan dalam Pasal 3 huruf (a) PP 11/2010, dinyatakan :

"Tidak termasuk obyek penertiban tanah terlantar sebagaimana dimaksud dalam

Pasal 2 adalah: (a) tanah Hak Milik atau Hak Guna Bangunan atas nama perseorangan yang secara tidak sengaja tidak dipergunakan sesuai dengan keadaan atau sifat dan tujuan pemberian haknya".

Yang dalam penjelasan dengan tegas di jabarkan sebagai berikut :

"Yang dimaksud dengan "tidak sengaja tidak dipergunakan sesuai dengan keadaan atau sifat dan tujuan pemberian haknya" dalam ketentuan ini adalah karena Pemegang Hak perseorangan dimaksud tidak memiliki kemampuan dari segi ekonomi untuk mengusahakan, mempergunakan, atau memanfaatkan sesuai dengan keadaannya atau sifat dan tujuan pemberian haknya". 
Dalam hal tidak sengaja karena ketidakmampuan segi ekonomi dikarenakan sebab keadaan ekonomi yang mengkibatkan penurunan kemampuan, bisa saja terjadi kepada badan hukum swasta, seperti keadaan krisis moneter yang menyebabkan kemampuan rencana pembanguan badan hukum tidak dapat terlaksana, hal ini dapat juga dikatagorikan dengan yang dimaksud dengan tidak sengaja, dan seharusnya dapat di pertimbangan penurunan segi ekonomi seperti ini tidak menjadi kesengajaan, karena tidak dapat dikatakan kelalaian dalam memenuhi kewajiban yang ditentukan dalam pemberian hak tanah tersebut.

Hal menarik apa yang dinyatakan dalam pasal 1 ayat (4) UUPA tentang pengertian tanah, yaitu dipermukaan bumi yang ada didarat dan juga permukaan bumi yang berada dibawah air, jika dikaitkan dengan apa yang dimaksud dengan hapusnya hak kepemilikkan karena musnah dalam pasal 40 huruf (f) UUPA dijelaskan "Hak Guna Bangunan hapus salah satunya karena tanahnya musnah", dapat diambil kesimpulan bahwa tanah yang abrasi dapat dikatakan tidak bukan musnah dikarenakan yang dimaksud pengertian tanah, juga permukaan bumi yang berada dibawah air. Hal terjadi terhadap tanah kepemilikkan HGB tidak dapat katakan musnah karena termasuk dalam pengertian penurunan permukaan tanah dari darat menjadi dibawah air. Disamping itu kata musnah dalam Kamus Bahasa Indonesia adalah binasa, selanjutnya pengertian binasa adalah rusak sama sekali, hancur lebur, maka makna musnah dalam pengertiannya kerusakkan yang mengkibatkan bentuk dan rupa tidak bisa dipergunakan lagi dan mungkin juga tidak dapat dilihat atau dirasakan. Berbeda dengan maksud pengertian tanah yang abrasi, tidak dapat dikatakan sebagai tanah yang musnah dikarenakan bukan dalam persepsi kerusakkan yang menghilangkan bentuk dan tidak bisa dipergunakan lagi.

Proses pengembalian hak kepemilikkan sertipikat oleh Perusahaan yang musnah karena abrasi, dalam kaitan pelaksanaan pemanfaatan peruntukkan tanah penanaman modal untuk pembangunan oleh Perusahaan atas ijin lokasi yang dahulu diberikan/dipegang berdasarkan penetapan pemerintah kepada Perusahaan, dan untuk mendapatkan hak kepemilikkan atas tanah yang telah bersertipikat HGB berdasarkan pemanfaatan peruntukkan oleh Perusahaan, disamping yang terpenting bagaimana mengembalikan Hak Kepemilikkan sertipikat milik Perusahaan yang telah musnah tanahnya tersebut. Pelaksanaan rencana penanaman modal Perusahaan sesuai dengan ketentuan dimulai dari Penetapan Pemerintah Daerah seseuai kewenanangan yang ditentukan Undang-Undang Nomor 32 Tahun 2004 Pasal 14 ayat (1) huruf (k) dan Peraturan Presiden Nomor 10 Tahun 2006, tentang Badan Pertanahan Nasional, maka semua kewenangan yang berkaitan dengan Pelayanan pertanahan yang dimaksud dalam Pasal 14 ayat (1) huruf (k) diberikan kepada Badan pertanahan Nasional, sebagaimana yang diatur dalam Pasal 2 yang menyatakan bahwa Badan Pertanahan Nasional (BPN) melaksanakan tugas pemerintahan dibidang pertanahan secara nasional, regional, dan sektoral.

Untuk melihat upaya Perusahaan mendapatkan pemanfaatan peruntukkan tanah penananaman modal pembangunan tersebut, setelah dilakukan kesepakatan dengan nota kesepahaman/kesepakatan (memorandum of undestanding antara Perusahaan sebagai pemilik sertipikat-sertipikat HGB (dikantakan demikian karena ijin lokasi pemanfaatan telah daluarsa) dan pemegang penetapan pemanfaatan peruntukkan tanah dan Perusahaan sebagai investor yang akan membeli hak kepemilikkan tanah sertipikat-sertipikat HGB dan pemohon baru atas perubahan peruntukkan ijin lokasi diarea tersebut, maka dilakukan langkah-langkah permohonan penetapan pemerintah yang sesuai dengan Undang-Undang Nomor 32 Tahun 2004 Pasal 14 ayat (1) huruf (k) dan Peraturan Presiden Nomor 10 Tahun 2006,

Setelah Perusahaan mendapatkan penetapan pemerintah tersebut maka proses peralihan hak atas tanah kepemilikkan HGB Perusahaan dapat dilaksanakan dengan proses jual beli dengan sistem pemdaftaran akta untuk peralihan hak, yang dilakukan dengan pembuatan Akta Jual Beli dihadapan PPAT, sesuai Keputusan Presiden Republik Indonesia Nomor 34 tahun 2003 dan Surat Edaran Kepala Badan Pertanahan Nasional Nomor 110-1316 tanggal 31 Mei 2003, terhadap tanah dengan status Hak Guna Bangunan dapat langsung dibalik nama setelah 
Akta Jual Beli, dan terhadap tanah masyarakat yang berupa hak tanah milik dan milik adat dilakukan dengan Akta Pelepasan Hak..

Dalam Peraturan Menteri lingkungan hidup Nomor 05 tahun 2012 tentang Rencana Usaha dan/Kegiatan yang wajib memiliki Amdal, pertimbangan dampak penting yang akan timbul akibat penguruggan yang akan dilakukan oleh Perusahaan, yang akan menimbulkan dampak terhadap lingkungan hidup perlu dianalisis sejak awal perencanaan, sehingga langkah pengendalian dampak negatif dan pengembangan dampak positif dapat dipersiapkan sedini mungkin. Penyusunan dokumen Amdal wajib mengacu kepada kebijakan yang diterbitkan kementerian lingkungan hidup yang bertujuan dan manfaat untuk Perusahaan, Pemerintah dan masyarakat, sebagai berikut :

1) Kegunaan bagi Perusahaan.

a. Membantu proses pengambilan keputusan tentang kelayakkan lingkungan hidup dari rencana usaha dan/atau kegiatan;

b. Memberikan masukkan untuk penyusunan disain rinci teknis dari rencana kegiatan;

c. Memberikan masukkan untuk penyusunan rencana pengelolaan dan pemantauan lingkungan hidup dan rencana kegiatan;

d. Memenuhi kententuan perundan-undangan dan peraturan dibidang lingkungan hidup.

2) Kegunaan bagi Pemerintah.

a. Sebagai bahan masukkan dalam pereancanaan wilayah sesuai rona lingkungan awal dan tingkat kegiatan pembangunan yang akan dilakukan;

b. Mencegah atau mengurangi kerusakkan lingkungan disekitar lokasi yang menimbulkan dampak turunan berkelanjutan pada keadaan lingkungan disekitarnya

3) Kegunaan bagi masyarakat.

a. Wadah memberikan informasi bagi masyarakat sekitar, sehingga dapat menghindari dampak negatif dan pemanfaatan dampak positif pelaksanaan kegiatan pembangunan;

b. Sebagai bahan masukkan bagi masyarakat untuk merencanakan usaha yang sesuai dengan kondisi rona lingkungan serta kondisi yang akan datang sehubungan denga adanya kegiatan pembangunan.

Setelah mendapat kerangka acuan amdal, maka Perusahaan melakukan pelaksanan pengembalian batas tanah dengan merevitalisasi lahan dengan penguruggan dan membuat bangunan penahan gelombang atau tanggul pantai permanen agar dampak abrasi tidak terulang kembali dan/atau meluas. Pelaksanaan revitalisasi lahan dilakukan sesuai letak dan luasan tanah yang telah ditentukan sesuai dengan gambar di bawah ini, keadaan dimana sebelum dilakukan penguruggan terhadap kepemilikkan atas tanah berdasarkan sertipikat HGB tersebut diatas.

Setelah dilakukan penguruggan atas bidang tanah atas sertipikat-sertipikat tersebut diatas, dan telah dilakukan pelaksanaan peninjauan oleh Kantor Badan Pertanahan Nasional Kabupaten Bekasi, maka proses pendaftara Akta Jual Beli dapat ditindaklanjuti dengan proses balik nama sertipikat-sertipikat yang sebelumnya terkena musnah karena Abrasi dari Perusahaan, sesuai keada tanah dilapangan atas bidang tanah yang telah dilakukan revitalisasi batas tanah.

Setelah selesainya revitalisasi maka keadaan musnahnya tanah yang dimaksud dalam pasal 40 huruf (f) UUPA dijelaskan "Hak Guna Bangunan hapus salah satunya karena tanahnya musnah", atas tanah milik Perusahaan tidak berlaku, dan setelah dilakukan revitalisasi PERUSAHAAN dapat melanjutkan master plan perencanaan pembangunan dan melakukan perpanjangan dan/atau pemisahan sertipikat sesuai dengan bidang- bidang tanah yang telah ditentukan dalam master plan.

\section{B. Analisis Kedudukan Hukum Kepemilikkan Hak Atas Tanah Yang Telah Bersertipikat Yang Terkena Abrasi.}


Dengan undangkannya UUPA sebenarnya masalah-masalah dasar yang menyangkut politik hukum agraria sudah diselesaikan dan dikristalisasikan dalam norma hukum yang sifatnya masih pokok pada tanggal 24 September 1960. Tuntutan merealisasikan tuntutantuntutan yurudis yang berkenaan dengan berlakunya UUPA, yaitu keharusan pemerintah untuk membuat peraturan -peraturan lanjutan yang sesuai dengan ketentuan ruang lingkup UUPA, agar tetap relevan dengan tuntutan perkembangan zaman, yang dapat menampung dan menyelesaikan berbagai masalah kekinian ${ }^{3}$. Relevansi tersebut menurut Maria S.W. Sumardjono Relevansi terkait erat dengan beberapa asas yang dimiliki seperti fungsi sosial, asas land-reform, dan asas perencanaan pengunaan tanah untuk kesejahteraan bersama ${ }^{4}$.

Akar masalah adalah kenyataan bahwa luas tanah tidak bertambah, sedangkan penghuninya terus bertambah dan perkembangan masyarakat dengan berbagai kegiatan penunjang kehidupan dan perekonomian, disamping tantangan gejala alam yang bersifat merusak dan menghilangkan fungsi tanah yang mengakibatkan musnahnya tanah karena sama sekali tidak dapat dikuasai lagi secara fisik dan mungkin juga secara fisik tidak diketahui lagi keberadaanya. Hal ini yang kemudian sering menimbulkan masalah sosial yang terindentifikasi sebagai masalah tanah.

Sesuai dengan maksud penamaannya sebagai Undang-undang Pokok, maka UUPA masih memerlukan berbagai peraturan pelaksanaan untuk mengoperasikannya. Sebab ia baru merupakan bet het in rust atau hukum dalam keadaan tidak bergerak. Tetapi berbagai peraturan pelaksanaan yang diperlukan sangat lambat pembuatannya, ibarat keluar setetes demi setetes",

Menurut Maria S.W. Sumardjono salah satu masalah yang memungkinkan timbulnya masalahmasalah rumit dalam soal tanah di indonesia adalah terlalu lambat pembuatan perangkat peraturan pelaksanaan atas UUPA. Diingatkan bahwa UUPA tidak dapat berdiri sendiri, melainkan membutuhkan berbagai peraturan pelaksanaan ${ }^{6}$.

Menyangkut hapusnya hak atas tanah yang bersangkutan musnah, demikian dinyatakan dala pasal 27 huruf b, 34 huruf f, dan 40 huruf f. Kirannya sudah dengan sendirinya hak yang bersangkutan menjadi hapus, kalau tanah yang dihaki musnah. Tanah musnah kalau menjadi hilang karena proses alamiah ataupun bencana alam, sehingga sama sekali tidak dapat dikuasai lagi secara fisik dan tidak pula dapat dipergunakan lagi, karena secara fisik tidak diketahui lagi keberadaannya. Misalnya tanah tepi laut atau sungai besar yang hilang karena proses alamiah berupa abrasi atau longsor karena bencana alam $^{7}$

Penjelasan Boedi Harsono tentang kriteria musnah tanah tersebut memang sudah sangat jelas, keadaan dari musnah tanah mengakibatkan hapusnya hak, dan tanahnya jatuh kepada kekuasaan negara, pengertian tersebut juga dijelaskan dalam Peraturan Kepada Badan Pertanahan Nasional Republik Indonesia nomor: 6 tahun 2010 tentang Penanganan Bencana Dan Pengembalian Hak-hak Masyarakat Atas Aset Tanah Di Wilayah Bencana pasal 1 angka (9), bahwa pengertian "Tanah musnah adalah tanah yang sudah berubah dari bentuk asalnya karena peristiwa alam dan tidak dapat diidentifikasi lagi sehingga tidak dapat difungsikan, digunakan dan dimanfaatkan sebagaimana mestinya".

Penerapan serta merta hapusnya hak atas tanah karena musnahnya tanah dalam UUPA adalah jelas dan final, tidak ada pengecualian aktivitas atau keadaan yang menganulir hapusnya hak karena musnah tanahnya, bila dibandingan tanah ditelantarkan dapat dikecualikan dengan ketidak sengajaan karena kemunduran/ketidakmampuan ekonomi. Keadaan musnah dengan

\footnotetext{
${ }^{3}$ Moh. Mahfud MD, Politik Hukum di Indoensia, Cetakan Enam, (Jakarta: Rajawali Pers, 2014), hlm 279.

${ }^{4}$ Maria S.W. Sumardjono, “Relevansi UUPA setelah 32 tahun” dalam harian Pos 24 September 1992, hlm. IV

${ }^{5}$ Iman Sutikno, Politik Agraria, (yogyakarta : Gajah Mada Unoversity Press, 1990, hlm 95.

${ }^{6}$ Moh. Mahfud. Op.Cit. hlm. 281

${ }^{7}$ Boedi Harsono, Op.Cit., hlm. 340.
} 
Otentik's: Jurnal Hukum Kenotariatan (Vol 2, No. 1, Januari 2020)

p-ISSN 2655-5131 e-ISSN 2685-3612

dasar perubahan bentuk asal tanah karena peristiwa alam secara fisik mengakibatkan tidak dapat dindetifikasi dikarenakan ketidak ada keyakinan mengenai letak, hamparan, perbatasan dan maupun luas atas bidang tanah. Perubahan dari bentuk asal baik faktor alam dan faktor lingkungan, yang dapat menghilangkan rupa permukaan bumi yang tidak sesuai dengan kondisi asal dan sulit dilakukan penyesuaian pengukuran untuk pendaftaran tanah maka akan sulit dikembalikan hak kepemilikkannya, hanya yang tersisa masih ada yang mungkin dapat diberikan hak kepemilikkan, yang telah tidak terindentifikasi (tidak terlihat atau dirasakan) dan ditidak dapat difungsikan, digunakan dan dimanfaatkan sebagaimana mestinyaakan dikatakan tanah musnah, sebagai contoh tanah di tepi pantai, setelah abrasi maka sisa tanah yang ada saja yang dapat dimiliki oleh pemegang hak.

Terhadap sertipikat Hak Guna Bangunan yang dimiliki pemegang hak, bilamana tidak ada tanahnya atas sertipikat tersebut musnah seluruhnya, dengan sendirinya hapus hak kepemilikkan dan hanya terdaftar dalam administrasi pertanahan di Kantor Badan Pertanahan Nasional dimana sertipikat tanah Hak Guna Bangunan tersebut berada. Maka sertipikat bukan lagi sebagai bukti kepemilikkan hak atas tanah, sertipikat hanya membuktikan pemegang hak pernah memiliki tanah yang diberikan hak dan terdaftar dalam Pendaftaran tanah sesuai ketentuan Peraturan Pemerintah Republik Indonesia Nomor 24 tahun 1997, yang selanjutnya PP 24/1997.

Untuk ketertiban administrasi dan kepastian hukum bagi pihak-pihak yang bersangkutan, hapusnyanya hak atas tanah harus dinyatakan dengan Surat Keputusan oleh Pejabat yang berwenang. Bagi hapusnya hak yang terjadi karena hukum, seperti yang ditentukan dalam pasal 21 UUPA, Surat Keputusan tersebut hanya bersifat deklaratoir, sebagai pernyataan tentang hapusnya hak yang bersangkutan. Tetapi bagi hapusnya hak karena pembatalan, karena tidak dipenuhi kewajiban tertentu oleh pemegan haknya, seperti yang dimaksud dalam UndangUndang 29 tahun 1956 tentang Peraturan-peraturan dan Tindakan-tindakan mengenai tanah Perkebunan (LN 1956-74, TLN 1126 dalam Boedi Harsono, ibid. Kode E3). Surat Keputusan Pejabat tersebut bersifat konstitutif. Dalam arti hak bersangkutan baru menkadi hapus dengan dikeluarkannya Surat Keputusan tersebut. Mengenai ha-hak atas tanah primer, tanah yang bersangkutan menjadi tanah Negara. ${ }^{8}$.

Untuk menuju adanya kepastian hukum terhadap tanah, maka dengan dilakukan pendaftaran tanah, dengan tujuan pendaftaran tanah oleh Badan Pertanahan Nasional menurut ketentuan UUPA dan PP 24/1997 adalah untuk memberikan perlindungan hukum dan kepastian hukum kepada pemegang hak atas tanah suatu tanah melalui sertifikat hak atas tanah yang terdaftar agar dengan mudah membuktikan dirinya sebagai pemegang hak. Untuk memberikan informasi kepada pihak-pihak yang berkepentingan termasuk Pemerintah terutama mengenai batas-batas tanah karena melalui pendaftaran tanah dapat diketahui berapa luas dan batas-batas sebidang tanah. Kepastian hukum dibuktikan dengan pemberian bukti kuat kepemilikkan otentik dari Badan Pertanahan Nasional, merupakan bagian-bagian penyelenggaraan kepastian hukum demi keamanan dan ketertiban Negara Kesatuan Republik Indonesia, dengan maksud pelembagaan hak atas tanah dilakukan untuk menjamin keteraturan dan kejelasan penguasaan dan kepemilikkan demi menjaga keadilan dalam mempertahankan hak dan menghindari ke kawatiran-kewatiran arogansi kekuasaan dan perbuatan pengambilan hak untuk atas nama kepentingan umum.

Kepastian hukum yang dimaksud oleh Gustav Radbruch adalah keadilan yang memberikan kepastian dan kebahagian secara zhahiriah dan bathiniah, dengan mengatur secara jelas pemberlakuan hukumnya dan logis dalam arti tidak menimbulkan keragu-raguan yang dijalankan secara konsisten dan konsekuen. Walaupun masih ada keraguan karena sertipikat

\footnotetext{
${ }^{8}$ Ibid. Hlm 332.
} 
hanya berkedudukan sebagai bukti kepemilikkan yang kuat bukan mutlak, dengan kedudukan kebenaran relatif selama tidak pihak lain yang menggugurkan/membuktikan sebaliknya kepemilikkan tanah tersebut. Setidaknya pelaksanaan pendaftaran tanah yang di inisiasi oleh pemerintah berdasarkan UUPA dan PP 24/1997, merupakan pemberlakukan hukum yang logis dan tidak menimbulkan keragu-raguan yang dijalankan secara konsisten dan konsekuen. Konsisten dengan maksud diselengarakan pendaftaran tanah secara terus menerus dengan pola ajudikatif secara sisttimatis yang diselengarakan oleh Pemerintah cq. Badan Pertanahan Nasional dan pendaftaran tanah dengan kemauan/kebutuhan pemilik tanah dengan pola Sporadik. Konsekuen dengan maksud apa yang di menjadi dasar hukum alas hak pembuatan tanah merupakan kebenaran yuridis administratif dari pemilik tanah tanpa pengecualian, dengan konsekuensi akibat hukum hilangnya hak atas tanah dan bayang-bayang hukum publik dengan pengekangan kebebasan (penjara), bilamana terbukti secara meyakinkan dengan pelaksanaan delik aduan (laporan).

Karena sistem pendaftaran tanah yang dianut UUPA adalah publikasi negatif cenderung positif, karena pemerintah sebagai pemegang kewenangan yang menguasai hak penguasaan atas bumi di Negara Kesatuan Republik Indonesia tidak menjamin pengembalian hak yang telah memiliki sertipikat, jika dibuktikan sebaliknya kebenaran hukum alas hak atas sertipikat tersebut, dan Kantor Pertanahan Nasional hanya bersikap aktif yaitu hanya membukukan dan mencatat pendaftaran hak. Dan cenderung positif karena pola pemberian sertipikat hak atas tanah dengan jalan pendaftaran tanah, baik pendaftaran hak atau pendaftaran akta.

Dengan memiliki sertipikat, maka kepastian hukum berkenaan dengan jenis hak atas tanah, subyek hak, dan obyek haknya menjadi nyata. Pendaftaran hak atas tanah akan menghasilkan ${ }^{9}$ :

a. Kepastian hak atas tanah Dari segi yuridis mengenai status haknya, siapa yang berhak atasnya (siapa yang mempunyai) dan atau tidaknya hak-hak dan kepentingan pihak lain. Ini diperlukan karena status tanah itu bermacam-macam yang masing-masing memberikan wewenang dan meletakkan kewajiban-kewajiban yang berbeda kepada pihak yang mempunyai.

b. Kepastian subyek haknya Kepastian mengenai siapa yang mempunyai tanah diperlukan untuk mengetahui dengan siapa kita berhubungan untuk dapat melakukan perbuatanperbuatan hukum secara sah mengenai ada atau tidaknya hak-hak dan kepentingan pihak ketiga diperlukan untuk mengetahui perlu atau tidaknya diadakan tindakan-tindakan tertentu untuk menjamin penguasaan dan penggunaan tanah yang bersangkutan secara efektif dan aman.

c. Kepastian obyek haknya Kepastian mengenai bidang teknis (yaitu kepastian mengenai letak, luas dan batas-batas tanah yang bersangkutan). Ini diperlukan untuk menghindari sengketa di kemudian hari baik dengan pihak yang menyerahkan maupun dengan pihakpihak yang mempunyai tanah yang berbatasan.

d. Kepastian hukumnya Bagi pemegang hak atass tanah Pendaftaran Tanah bermanfaat: memberikan rasa aman;

Kewajiban mendaftarkan tanah derivatif dilakukan setiap ada perubahan baik fisik maupun yuridisnya, agar terpeliharanya data yang up to date (mutakhir). Dengan terdaftarnya perubahan data fisik maupun yuridis dalam daftar umum pendaftaran tanah, seperti karena Keputusan Pejabat berwenang hapusnya hak atas tanah, pendaftaran itu akan merupakan alat pembuktian yang kuat bagi pemegang haknya terhadap tanah yang tersisa. ${ }^{10}$ Disebutkan dalam

\footnotetext{
${ }^{9}$ Arie. Hutagalung.S, dkk. Op.cit.hlm 285
}

\footnotetext{
${ }^{10} \mathrm{AP}$ Parlindungan, loc.cit
} 
Pasal 32 ayat (2), Pasal 38 ayat (2) UUPA, yang intinya bahwa pendaftaran termaksud dalam ayat (1) merupakan alat pembuktian yang kuat ${ }^{11}$.Sertipikat mempunyai kekuatan bukti seperti halnya akta otentik, karena dibuat oleh pejabat yang berwenang, bentuk dan tatacaranya diatur dengan undang-undang (UUPA). Jadi untuk memenuhi ketentuan akta otentik yang mempunyai kekuatan pembuktian yang kuat syaratnya adalah pembuatannya harus memenuhui ketentuan tentang pendaftaran tanah yang berlaku.

Hal yang diutarakan diatas menilai dari kreteria landasan penetapan hapusnya tanah karena musnahnya, selanjutnya musnahnya tanah dipelajari dari tingkat kerusakkan, apakah musnah tanah dapat dilakukan normalisasi dengan pengembalian permukaan tanah seperi semula (revitalisasi), sebagai berikut :

a. Kerusakkan yang tidak bisa ditanggulangi/diperbaiki

b. Kerusakkan yang dapat ditanggulangi

Dalam peraturan Menteri Agraria/Kepala Badan Pertanahan Nasional Nomor 17/ Permen Nomor 410-1293 menentukan tanah yang hilang secara alami, baik tanah abrasi pantai, tenggerlam atau hilang karena longsor, maka tanah-tanah tersebut dinyatakan hilang, dan haknya hapus dengan sendirinya. Selanjutnya pemegang hak tidak dapat minta ganti rugi kepada siapapun dan tidak berhak menuntut apabila di kemudian hari di atas bekas tanah tersebut dilakukan reklamasi penimbunan ataupun pengeringan.

Tanah-tanah yang di revitalisasi dengan jalan reklamasi dinyatakan sebagai tanah yang dikuasai oleh negara dan pengaturannya dilaksanakan oleh Menteri Negara/Kepala Badan Pertanahan Nasional. Pihak yang melakukan reklamasi dapat diberikan prioritas pertama untuk mengajukan permohonan hak atas tanah reklamasi tersebut.

Agar bumi (tanah), air dan ruang angkasa serta kekayaan alam yang terkandung didalamnya dapat memberikan manfaat sebesar-besanya bagi negara dan rakyat dalam arti kebangsaan, kesejahteraan dan kemerdekaan dalam masyarakat, maka dengan wewenang yang bersumber pada hak menguasai dari Negara, untuk digunakan mencapai sebesar-besarnya kepentingan Negara Hukum Indonesia yang merdeka, berdaulat, adil dan makmur.

Secara umum, negara Indonesia yang menganut paham negara hukum, hal ini ditetapkan dalam pasal 1 ayat (3) UUD 1945, yang menyatakan "Negara Indonesia adalah Negara Hukum", hukum sebagai panglima untuk melindungi seluruh tumpah darah, mensejaterahkan kehidupan sosial bagi seluruh rakyat Indonesia. Dalam menempuh tujuan mensejahterakan kehidupan sosial negara hukum selalu berlakunya tiga prinsip dasar, yakni supermasi hukum (supremacy of law), kesetaraan di hadapan hukum (equality before the law), dan penegakan hukum dengan cara tidak bertentangan dengan hukum (due process of law).

Pendapat Dr. Muhammad Hatta, The Founding Father, Negara bukan sekedar penjaga malam, Negara wajib mensejaterakan kehidupan bangsa, keterkaitan ini negara secara aktif menguapayakan kesajahteraan dan bertidaak adil yang dapat dirasakan seluruh masyarakat secara merata seimbang, yaitu dengan pelaksaan pembangunan yang meningkatkan harkat kehidupan dan ekonomi. Bahwa bumi (tanah), air, dan ruang angkasa serta kekayaan alam yang terkandung didalamya bukan merupakan milik Negara, akan tetapi pada tingkatan tertinggi dikuasai oleh negara sebagi organisasi kekuasaan seluruh rakyat yang diberi wewenang untuk mengatur dan menyelenggarakan peruntukkan, penggunaan, persediaan dan pemeliharaan atas bumi, air dan ruang angkasa, menentukan dan mengatur hubungan-hubungan hukum antara orang-orang dengan bumi, air dan ruang angkasa dimaksud serta menentukan dan mengatur hubungan-hubungan hukum mengenai bumi, air dan ruang angkasa dalam wilayah Republik Indonesia $^{12}$.

\footnotetext{
${ }^{11}$ Boedi Harsono, Hukum Agraria Indonesia: Himpunan Peraturan Hukum Tanah, op. cit, hlm.13

${ }^{12}$ Boedi Harsono, Op.Cit, hlm. 54.
} 
Otentik's: Jurnal Hukum Kenotariatan (Vol 2, No. 1, Januari 2020)

p-ISSN 2655-5131 e-ISSN 2685-3612

Gempa bumi dan bencana alam adalah fenomena alamiah yang dapat serta sering terjadi di mana saja dan kapan saja, faktor utama itu yang dapat mengakibatkan permukaan bumi (tanah) tidak sama sekali tidak dapat lagi dikuasai fisik dan secara fisik tidak diketahui keberadaannya. Bagi proses pembangunan fenomena alamiah ini dapat menganggu dan mungkin mengkibatkan kemunduran serta bisa tidak terlaksananya rencana pemanfaat lahan sesuai peruntukkan dan fungsinya dalam pembangunan. Kegiatan pengadaan tanah yang dilakukan untuk pelaksanaan penanaman modal untuk pembangunan, akan terdelusi oleh alam, karena berkurangnya atau hilangnya obyek pembangunan. Dalam pasal 40 huruf (f), bahwa Hak Guna banguna dapat hapus karena; .... (f) musnah tanahnya, maka dengan seketika tidak adanya permukaan bumi (tanah) tidak sama sekali tidak dapat lagi dikuasai fisik dan secara fisik tidak diketahui keberadaannya, maka seketika hapus hak atas tanahnya. Atas sertipikat hanya kebenaran administrasi negara mengenai atas wilayah bumi (tanah) yang musnah pernah diberikan hak dan tidak berlaku sebagai bukti kepemilikkan tanah, atas itu tidak bisa dipergunakan obyek hubungan-hubungan hukum atas tanah, seperti menjual dan menjaminkan sertipikat tersebut, yang mengakibatkan cacat hukum setiap hubungan hukum yang dialakukan atas sertipikat tanah tersebut, seperti hak tanggungan.

Kemajuan teknologi dalam pembangunan dapat menjadi solusi kemampuan untuk upaya pengembalian hak atas tanah yang musnah tanahnya, UUPA atau Peraturan pelaksana UUPA tidak mengatur perihal pengembalian hak atas tanah yang telah musnah, bahkan dalam Dalam peraturan Menteri Agraria/Kepala Badan Pertanahan Nasional Nomor 17/ Permen Nomor 410-1293 ditegaskan tanah yang hilang secara alami, baik tanah abrasi pantai, tenggerlam atau hilang karena longsor, maka tanah-tanah tersebut dinyatakan hilang, dan haknya hapus dengan sendirinya. Selanjutnya pemegang hak tidak dapat minta ganti rugi kepada siapapun dan tidak berhak menuntut apabila di kemudian hari di atas bekas tanah tersebut dilakukan reklamasi penimbunan ataupun pengeringan, dalam arti yang kegiatan yang dilakukan untuk kepentingan umum.

Kegiaatan pengembalian permukaan bumi tersebut, dengan melakukan revitalisasi dengan reklamasi, pengembalian tanah dengan pengeruggan dan atan pengeringan merupakan upaya terakhir yang dapat dilakukan pemegang hak untuk dapat mengembalikan hak kepemilikkan atas tanah yang musnah tanahnya. Pedoman revitalisasi dapat terlihat Peraturan Menteri Pekerjaan Umum No. 18 tahun 2010 pasal 1 ayat (1) tentang Pedoman Revitalisasi Kawasan, Revitalisasi adalah upaya untuk meningkatkan nilai lahan/kawasan dengan pembangunan kembali dalam suatu kawasan yang dapat meningkatkan fungsi kawasan sebelumnya. Revitalisasi adalah suatu proses cara dan atau perbuatan untuk menghidupkan atau menggiatkan kembali sebagai program kegiatan apapun, yang merupakan usaha-usaha untuk menjadikan sesuatu itu menjadi penting dan perlu sekali. Untuk melaksanakan hal tersebut setiap orang atau badan hukum wajib memiliki Kajian Lingkungan Hidup Strategi (KHLS) yang diatur dalam Undang-undang No. 32 Tahun 2009 tentang Perlindungan dan Pengelolaan Lingkungan Hidup, salah satu instrumen pencegahan pencemaran dan/atau kerusakan lingkungan adalah tata ruang. Pasal 19 UU PPLH menegaskan bahwa:

"Untuk menjaga kelestarian fungsi lingkungan hidup dan keselamatan masyarakat, setiap perencanaan tata ruang wilayah wajib didasarkan kepada KLHS (KajianLingkungan Hdiup Strategi). Perencanaa tata ruang wilayah sebagaimana dimaksud pada ayat (1) ditetapkan dengan memperhatikan daya dukung dan daya tampung lingkungan hidup".

KLHS menjadi kunci penting dalam pencegahan pencemaran dan/atau kerussakan lingkungan, KLHS merupakan rangkaian analisis yang sistematis, menyeluruh dan patisipasif untuk memastikan bahwa prinsip-prinsip pembangunan suatu wilayah. Dengan demikian, pemerintah pusat/daerah wajib melaksanakan KLHS dalam rangka penyususnan rencana tata 
Otentik's: Jurnal Hukum Kenotariatan (Vol 2, No. 1, Januari 2020)

p-ISSN 2655-5131 e-ISSN 2685-3612

ruang wilayah, rencana detail tata ruang, rencana pembangunan jangka panjang dan rencana pembangunan jangka menengah, baik nasional, provinsi maupun kabupaten/kota.

Setelah telaksananya revitalisasi dengan reklamasi, pengembalian tanah dengan pengeruggan dan atan pengeringan, pemegang hak wajib mengajukan permohonan pendaftaran tanah sesuai dengan yang telah ditentukan dalam PP 24/1997, agar kepastian hukum atas batas tanah dan pengembalian sertipikat hak atas tanah sebagai bukti kepemilikkan dapat kembali, dan sertipikat dapat mendapatkan fungsinya dalam kedudukannya dapat mengadakan hubunganhubungan hukum atas tanah.

Pelaksaana permohonan pendaftaran dilakukan ke Kantor Pertanahan Nasional setempat, dengan melakukanah tinjauan lokasi dan membuat berita acara pengembalian batas tanah dan melakukan pengukuran yang dilakukan oleh pegawai Kantor Badan Pertanahan Nasional setempat, yang kemudian Kepala Kantor Pertanahan Nasiona setempat membuat penetapan yang dicatatkan dalam buku tanah sertipikat, maka setelah itu sertipikat dalam kedudukannya kembali menjadi bukti kepemilikkan yang kuat yang dapat melakukan hubungan-hubungan hukum tanah yang mengaturnya.

Mengingat yang terjadi dalam keadaan hak kepemilikkan yang telah bersertipikat milik Perusahaan yang didapat dari pengalihan hak, keadaan fisik tanah tersebut telah musnah secara alamiah yang terus menurus, yaitu karena fenomena alam kenaikkan permukaan laut dan penggerusan tanah yang menyebabkan abrasi, sehingga permukaan tanah hilang dan tepi pantai yang menjadi lahan atas sertipikat menjadi mundur. Maka dengan serta merta hak kepemilikkan berdasarkan sertipikat atas tanah milik Perusahaan hapus hak dan sertipikat bukan bukti kepemilikkan.

Sedangkan pengertian sempit agraria yaitu pengertian bumi meliputi permukaan bumi (yang sebut tanah), tubuh bumi dibawahnya serta yang berada dibawah air (pasal 1 ayat 4 jo pasal 4 ayat 1), dengan demikian, pengertian "tanah meliputi permukaan bumi yang ada didaratan dan permukaan bumi yang berada dibawah air, termasuk air laut. ${ }^{13}$ Dan air temasuk didalamnya perairan pedalaman (inland waters) seperti sungai, danau, rawa, dan dilaut wilayah/laut teritorial Indonesia. ${ }^{14}$ Dalam keadaannya permukaan bumi dibawah permukaan air masih dikatagorikan dengan tanah yang dapat dianggap obyek pemberian hak atas tanah.

Melihat permasalahan tanah yang berlaku pada bidang tanah yang musnah karena abrasi milik Perusahaan, yang sebelumnya permukaan tanahnya meliputi/berada di bibir pantai/pinggir pantai, karena fenomena alamiah tersebut menjadi musnah, dan mengakibatkan sama sekali tidak dapat lagi dikuasai fisik dan secara fisik tidak diketahui batas tanahnya karena sekarang menjadi laut, permukaan tanah menurun dari daratan ke permukaan didalam air.

Mengingat yang dimaksud dengan musnah Peraturan Kepada Badan Pertanahan Nasional Republik Indonesia nomor: 6 tahun 2010 tentang Penanganan Bencana Dan Pengembalian Hak-hak Masyarakat Atas Aset Tanah Di Wilayah Bencana pasal 1 angka (9), bahwa pengertian "Tanah musnah adalah tanah yang sudah berubah dari bentuk asalnya karena peristiwa alam dan tidak dapat diidentifikasi lagi sehingga tidak dapat difungsikan, digunakan dan dimanfaatkan sebagaimana mestinya" dan dalam Kamus Besar Bahasa Indonesia bahwa musnah itu adalah binasa, selanjutnya pengertian binasa adalah rusak sama sekali, hancur lebur.

Maka makna musnah dalam pengertiannya kerusakkan yang mengkibatkan bentuk dan rupa tidak bisa dipergunakan lagi dan mungkin juga tidak dapat dilihat atau dirasakan. Berbaeda dengan maksud pengertian tanah musnah yang terjadi abrasi, tidak dapat dikatakan sebagai tanah yang musnah dikarenakan tidak tepat dalam persepsi kerusakkan yang menghilangkan bentuk dan tidak bisa dipergunakan lagi. Dengan mendasari apa yang dimaksud dengan sempit agraria yaitu pengertian bumi meliputi permukaan bumi (yang sebut tanah), tubuh bumi

\footnotetext{
${ }^{13} \mathrm{Ibid}, \mathrm{hlm} .7$.

${ }^{14}$ Arie.S. Hutagalung,dkk, Op.cit,hlm. 128-129
} 
dibawahnya serta yang berada dibawah air (pasal 1 ayat 4 jo pasal 4 ayat 1), pengertian "tanah meliputi permukaan bumi yang ada didaratan dan permukaan bumi yang berada dibawah air, termasuk air laut. Dan air temasuk didalamnya perairan pedalaman (inland waters) seperti sungai, danau, rawa, dan dilaut wilayah/laut teritorial Indonesia. Dalam keadaannya permukaan bumi dibawah permukaan air masih dikatagorikan dengan tanah yang dapat dianggap obyek pemberian hak atas tanah. Abrasi sendiri dalam pengertiannya proses pengikisan garis pantai yang mengkibatkan terganggu keseimbangan kepadatan permukaan tanah karena gejala alam kecil oleh tenaga gelombang laut dan arus laut yang bersifat merusak dan juga bisa terjadi gejala alam besar oleh peningkatan permukaan air laut, bukan musnah yang dimaksud dalam pnegertian Peraturan Kepada Badan Pertanahan Nasional Republik Indonesia nomor: 6 tahun 2010 tentang Penanganan Bencana Dan Pengembalian Hak-hak Masyarakat Atas Aset Tanah Di Wilayah Bencana pasal 1 angka (9) dan Kamus Besar Bahasa Indonesia.

Maka dapat disimpulkan bahwa tanah milik Perusahaan dapat dikatakan belum dikatakan musnah tanahnya, dengan pendangan sebagai berikut :

1. pasal 1 ayat 4 jo pasal 4 ayat 1 dalam pengertian "tanah meliputi permukaan bumi yang ada didaratan dan permukaan bumi yang berada dibawah air, termasuk air laut. Dan air temasuk didalamnya perairan pedalaman (inland waters).

Obyek tanah di bawah permukaan air merupakan obyek yang masih dapat dilakukan hubungan tanah dengan pemberian hak

2. Keadaan yang musnah tidak termasuk dalam pebgertian penafsiran musah yang dimaksud Peraturan Kepada Badan Pertanahan Nasional Republik Indonesia nomor: 6 tahun 2010 tentang Penanganan Bencana Dan Pengembalian Hak-hak Masyarakat Atas Aset Tanah Di Wilayah Bencana pasal 1 angka (9) dan Kamus Besar Bahasa Indonesia. Karena musnah karena abrasi pengikisan garis pantai yang mengkibatkan terganggu keseimbangan kepadatan permukaan tanah karena gejala alam kecil oleh tenaga gelombang laut dan arus laut yang bersifat merusak dan juga bisa terjadi gejala alam besar oleh peningkatan permukaan air laut, sehingga hanya terjadi pergeseran batas tanah, dari tanah daratan menjadi tanah dengan permukaan air.

3. Terjadinya musnah tanah bukan faktor kesengajaan dan tidak dilakukan pemeliharaan dan pemanfaatan tanah menurut fungsi yang dimaksudkan dalam pemberian hak, karena faktor ketidaksengajaan yang disebabkan karena kemunduran/ketidakmampuan segi ekonomi akibat keadaan diluar kemampuan Perusahaan karena dialami juga oleh negara karena krisis moneter.

4. Adanya upaya dengan kemampuan pengembalian batas tanah dengan revitalisasi lahan, dengan suatu kegiatan penimbunan kembali dengan penguruggan tanah, yang pelaksanaan kegiatannya disesuaikan dengan KLHS (KajianLingkungan Hdiup Strategi), agar pola dan pelaksanaan dapat berjalan dengan kerangka acuan yang dapat terukur dan terjadi keseimbangan lingkungan hidup.

Untuk itu permohonan dan pelaksaan revitalisasi lahan milik Perusahaan dapat dilaksanakan dan dijinkan untuk dilakukan.

\section{KESIMPULAN}

1. Pada Hakekatnya dalam Alenia Ke-IV UUD, tujuan hak menguasai dari negara membentuk suatu pemerintahan negara Indonesia yang melindungi segenap bangsa Indonesia dan seluruh tumpah darah Indonesia dan untuk memajukan kesejahteraan umum, mencerdakan kehidupan bangsa, yang menjadi pedoman-pedoman penyelenggaraan kemakmuran rakyat, salah satunya landasan hukum agraria yang termaktub dalam pasal 33 
Otentik's: Jurnal Hukum Kenotariatan (Vol 2, No. 1, Januari 2020)

p-ISSN 2655-5131 e-ISSN 2685-3612

ayat (3) UUD 1945 yang bunyinya sebagai Pengaturan kelembagaan serta hubungan hubungan hukum atas bumi, air dan ruang angkasa, termasuk kekayaan alam yang terkandung didalamya, dilaksanakan dengan penegasan dalam pasal 2 UUPA, untuk mengatur dan menyelenggarakan peruntukan, penggunaan, persediaan dan pemeliharaan bumi, air dan ruang angkasa tersebut, menentukan dan mengatur hubungan-hubungan hukum antara orang-orang dengan bumi, air dan ruang angkasa, menentukan dan mengatur hubungan-hubungan hukum antara orang-orang dan perbuatan - perbuatan hukum yang mengenai bumi, air dan ruang angkasa, yang dapat diberikan dan dipunyai oleh perorangan atau badan hukum

2. Hapusnya Hak atas tanah sertipikat HGB dijelaskan dalam pasal 40 huruf (f) yang mengakibatkan tanah kembali kepada tanah asal yaitu tanah negara dan tanah hak milik, yang dijelaskan dala pasal 36 dan pasal 56 UUPA, maka Sertipikat HGB bukan lagi sebagai bukti kepemilikkan hak atas tanah, hanya membuktikan pemegang hak pernah memiliki tanah yang diberikan hak dan terdaftar dalam Pendaftaran tanah PP 24/1997, yang mempunyai hak utama/privilige untuk mengajukan kembali. Dengan melakukan revitalisasi dengan jalan reklamai, maka yang dikuasai oleh negara, diatur dalam Peraturan Menteri Pekerjaan Umum No. 18 tahun 2010 pasal 1 ayat (1) tentang Pedoman Revitalisasi Kawasan dan Peraturan Pemerintah (PP) Nomor 8 Tahun 1953, tentang Penguasaan Tanah Negara (LN Tahun 1953 Nomor 14 TLN Nomor 362).

Peraturan Pemerintah Republik Indonesia nomor 15 tahun 2010 tentang Penyelenggaraan Penataan Ruang yang selanjutnya disebut PP 15/2010, bahwa pengaturan penataan ruang diselenggarakan untuk mewujudkan ketertiban dalam penyelengaraan penataan ruang, memberikan kepastian hukum bagi seluruh pemangku kepentingan dalam melaksanakan tugas dan tanggung jawab serta hak dan kewajiban dalam penataan ruang, dan mewujudkan keadilan bagi seluruh pemangku kepentingan dalam seluruh aspek penyelenggaran penataan ruang.

3. Kebijakan penatagunaan bertujuan untuk Pengendalian pemanfaatan ruang menurut, dalam Pasal 35 UU 24/992, dilakukan melalui penataan peraturan Zonasi (Zoning) yang merupakan arahan peraturan zonasi sistem provinsi dan perturan zonasi pada wilayah kabupaten/kota, yang saling berkaitan satu sama lain, Perizinan yang menurut Pasal 163 PP No. 15 Tahun 2010 berupa: Izin prinsip berupa SPPL (Surat Penunjukan Penggunaan Lahan), Izin lokasi, Izin penggunaan pemanfaatan tanah, Izin mendirikan bangunan, dan Izin lain berdasarkan ketentuan peraturan perundang-undangan izin pemanfaatan ruang yang berkaitan peraturan perundangan sektoral lainnya, seperti lingkungan hidup, perhubungan dan lain- lain.

\section{Saran}

1. Seyogyakan badan hukum yang memiliki atau menguasai kepemilikkan yang diberikan sesesuai peruntukkan dengan pemberian hak, disertai menjalankan fungsi sosial yang telah ditetapkan agar keberhasilan pembangunan dapat dirasakan. Dan musnahnya tanah didaftarkan kepada Badan Pertanahan Nasional dan meminta tinjauan aspek tanah agar mendapat perlindungan hukum serta upaya yang harus dilakukan oleh pemegang hak (badan hukum)

2. Seyogyanya menghindari sifar kesengajaan tidak melakukan pemanfaatan tanah, dengan melakukan upaya yang telah ditentukan dalam KLHS (Kajian Lingkungan Hidup Strategi) dalam proses pembangunan, sehingga tidak dinyatakan ditelantarkan sehingga hapus haknya.

\section{DAFTAR PUSTAKA}


Otentik's: Jurnal Hukum Kenotariatan (Vol 2, No. 1, Januari 2020)

p-ISSN 2655-5131 e-ISSN 2685-3612

\section{Buku}

Ali Abdullah, Buku Ajar : Hukum Agraria Di Indonesia Dalam Perkembangan Pembentukkan Hukum Tanah Nasional, Jakarta, Program Magister Universitas Pancasila, 2017.

A. Sodikin, Penataan Pemilikkan Hak Atas Tanah di Daerah Perkebunan Kabupaten Malang, Studi Tentang Dinamika Hukum, Surabaya: Universitas Airlangga Surabaya, 1992

Ari Hutagalung dkk, Hukum Pertanahan Belanda, dan Indonesia, Denpasar:Pustaka Larasan; Jakarta: Unirversitas Indonesia, Universitas Leiden, Universitas Groninggen, Jakarta Lembaga Pemberdayaan Hukum Indonesia, 2000.

Ari Hutagalung, Setebar Pemikiran Seputar Masalah Hukum Tanah, Jakarta Lembaga Pemberdayaan Hukum Indonesia, 2000.

Ari Hutagalung, Serba Serbi Masalah Tanah Dalam Kegiatan Ekonomi, Jakarta, Badan Penerbit Fakultas Hukum Indonesia, 2002.

Arie.S.Hutagalung, dkk, Hukum Pertanahan di Belanda dan Indonesia, Denpasar:Pustaka Larasan; Jakarta: Unirversitas Indonesia, Universitas Leiden, Universitas Groninggen, 2012.

Ali Abdullah, Buku Ajar : Hukum Agraria Di Indonesia Dalam Perkembangan Pembentukkan Hukum Tanah Nasional, Jakarta, Program Magister Universitas Pancasila, 2017.

Ade Saptomo,Budaya Hukum \& Kearifan Lokal sebagai sebuah perspektif perbandingan, Jakarta:Fakultas Hukum Universitas Pancasila, 2019.

Fansz Magis Suseno, Etika Politik Prinsip-Prinsip Moral Dasar Kenegaraan Moden, (Jakarta: Gramedia, 2001)

Budi Harsono Hukum agraria indonesia, sejarah pembentukkan undang -undang pokok agraria, isi dan pelaksanaannya. Djambatan. Edisi Keduabelas. Jakarta. 2008.

Budi Harsono Undang-Undang Pokok Agraria dan Peraturan pelaksanaanua, Djambatan. Edisi Keduabelas. Jakarta. 2008.

Departemen Pendidikan Dan Kebudayaan, Kamus Besar Bahasa Indonesia, Edisi Kedua, Jakarta: Balai Pustaka Departemen Pendidikan Dan Kebudayaan, 1994,Cet. III

Fansz Magis Suseno, Etika Politik Prinsip-Prinsip Moral Dasar Kenegaraan Moden, Jakarta: Gramedia, 2001.

Haji Salim HS, Penerapan Teori Hukum Pada Penelitian Tesis dan Disertasi, Depok, RajaGrafindoPersada, Cetakan Ke Lima, 2017.

Iman Sutikno, Politik Agraria, (yogyakarta : Gajah Mada Unoversity Press, 1990.

Kamus Besar Bahasa Indonesia. Pusat Bahasa. Edisi Keempat. Departemen Pendidikan Nasional. Jakarta. PT Gramedia Pustaka Utama. 2014.

Moh. Mahfud MD, Politik Hukum di Indoensia, Cetakan Enam, Jakarta: Rajawali Pers, 2014.

Purnadi Purbacaraka dan Soerjono Soekanto, Perihal Kaedah Hukum, Bandung: PT. Citra Aditya,1993.

Romli Atmasasmita, Teori Hukum Integratif : Rekonstruksi Terhadap Teori Hukum Pembangunan dan Teori Hukum Progresif, Yogyakarta, Genta Publishing, Cetakan Pertama, 2012. 
Teguh Prasetyo Cs, Filsafat, Teori, dan Ilmu Hukum : Pemikiran Menuju Masyarakat Yang Berkeadilan dan Bermartabat, Depok, RajaGrafindo Persada, cetakan 4, 2014.

Nurus Zaman, Politik Hukum Pengadaan Tanah: Antara Kepentingan Umum dan Perlindungan Hak Azasi Manusia, Bandung, Refika Aditama, 2016.

Soekanto, Soerjono. Pengantar Penelitian Hukum. Jakarta. Universitas Indonesia (UI Press). 1986.

Soekanto, Soerjono dan Sri Mamudji, Penelitian Hukum Normatif, Suatu Tinjauan Singkat. Cetakan Ke-15. Jakarta. PT. Rajagrafindo Persada. 2013.

\section{Peraturan Perundang-Undangan}

Indonesia. Undang-Undang Nomor 5 Tahun 1960 tentang Peraturan Pokok Agraria .

Indonesia. Undang-Undang Nomor 20 Tahun 1961 tentang Pencabutan Hak-Hak Atas Tanah Dan Benda-Benda Yang Ada Diatasnuya .

Indonesia. Peraturan Pemerintah Nomor 40 Tahun 1996 tentang Hak Guna Usaha, Hak Guna Bangunan dan Hak Pakai Atas taah .

Indonesia. Peraturan Pemerintah Nomor 24 Tahun 1997 tentang Pendaftaran Tanah.

Indonesia. Keputusan Menteri Negara Agraria/Kepala Badan Pertnahan Nasional Nomor 21 Tahun 1994 tentang Tata Cara Perolehan Tanah Bagi Perusahaan Dalam Rangka Penanaman Modal .

Indonesia. Keputusan Menteri Negara Agraria/Kepala Badan Pertnahan Nasional Nomor 3 Tahun 1997 tentang Ketentuan Pelaksanaan Peraturan Pemertintah Nomor 24 Tahun 1997 Tentang Pendaftaran Tanah

\section{Internet}

Wikipedia bahasa Indonesia, diunduh tanggal 21 Juni 2019 terdapat dalam situs: https://id.wikipedia.org/wiki/Paradigma

\section{Jurnal}

Maria S.W. Sumardjono, "Relevansi UUPA setelah 32 tahun” dalam harian Pos 24 September 1992.

Mahruf. Analisi Hapusnya HGU Berdasarkan Surat Keputusan Penetapan Tanah Telantar Dari BPN, (Studi Kasus Atas Putusan Nomor 25/G/20013/PTUN.JKT). Jurnal Ilmu dan Budaya. Volume 40. No.55, Maret 2017.

Asyer Andrawan. Revitalisasi Atas Tanah Yang Hilang Akibat Abrasi Menurut Undang - Undang Nomor 5 Tahun 1960, Jurnal Lex Adminiistratum. Volume 5, No. 2, Maret-April Tahun 2013.

Jimly Asshiddiqie. Ideologi, Pancasila dan Konstitusi, Jurnal Makmah Konstiutsi tahun 2017. 